\title{
Biometrics as a determinant of the origins of seabirds killed in oil spills and other incidents
}

\author{
ROBERT T. BARRETT, TYCHO ANKER-NILSSEN, VIDAR BAKKEN, HALLVARD \\ STRØM, YURI KRASNOV and TOMAS AARVAK
}

\section{Summary}

Common Guillemots Uria aalge and Brünnich's Guillemots $U$. lomvia are common victims of oil spills, drowning in fishing nets and winter wrecks. Because the Norwegian population of Common Guillemots is classified as critically endangered and the Russian population of the Brünnich's Guillemot has declined greatly, it is important to be able to identify the origins of birds killed outside the breeding season. Measurements of birds made in nine colonies in the Barents and Norwegian Seas showed that although it is impossible to determine with reasonable accuracy the colony of origin from body measurements, the most likely sea of origin of Common Guillemots may be determined on the basis of wing and head + bill lengths, whereas there was no systematic variation in any measurement of Brünnich's Guillemots.

\section{Introduction}

With more than seven million pairs of some 40 species breeding in about 2,00o colonies, the Norwegian and Barents Seas are among the richest seabird areas in the world (Anker-Nilssen et al. 2000). The largest colonies are in Svalbard (including Bjørnøya [Bear Island] and Hopen), the west coast of Novaya Zemlya, the Murman coast, and the coast of northern Norway. Whereas many populations were heavily hunted and harvested for eggs, feathers and meat in the $19^{\text {th }}$ and $2 \mathrm{O}^{\text {th }}$ centuries, fisheries and oil pollution are considered to be among the greatest threats today. Oil and gas production started in the North Sea in the 1960s and has since spread northwards into the Barents Sea. Huge reserves have also been found in the Russian sector of the Barents Sea as well as on land in Northwest Russia and there is already a large traffic of tankers carrying oil westwards into the North Atlantic and to European ports (Bambulyak and Frantzen 2005). Several assessments of the vulnerability of the environment, including seabirds, to oil pollution have been made for the region and all concluded that, in whatever area or season, many seabird populations of international conservation value will be in danger of being seriously affected in the event of an oil spill (e.g. Arctic Council Oil and Gas Assessment, in prep.).

Because auks spend most of their life at sea, are surface-divers, and tend to spend most of their time in dense flocks on the sea surface, they are among those most vulnerable to long-term effects of oil pollution at the population level (e.g. King and Sanger 1979, Anker-Nilssen 1987, Camphuysen et al. 1999). In Norway, Common Guillemots Uria aalge and Brünnich's Guillemots U. lomvia are among the most conspicuous casualties of oil spills. For example, a small oil spill in North Norway in March 1979 killed an estimated 10,000-20,000 Brünnich's Guillemots (Barrett 1979) and another in the Skagerrak in December 1980 killed more than 60,000 Common Guillemots (Anker-Nilssen and Røstad 1982). Similarly, outside Norwegian waters, Common Guillemots have been very common victims of oil spills (Grantham 2004). Guillemots are also often killed in winter 'wrecks', often as a result of starvation during a period of food shortage and/or bad weather, or sometimes in fishery by-catch incidents. For example, an 
estimated 200,000 guillemots (mostly Common) drowned in an extraordinary fishing incident in North Norway in April 1985 (Strann et al. 1991).

When the Norwegian population (excluding the Svalbard archipelago) of Common Guillemot was first counted in the 1960s, it was already under increasing pressure from hunting, egg harvesting, drowning in fishing gear and oil spills (Brun 1969). Since then the numbers have collapsed from Brun's estimate of 120,000-160,000 pairs to the alarmingly low estimate of only 15,000 pairs today (Barrett et al. 2006). Although two thirds of these birds breed in the far north of Norway (Finnmark) where there are signs of a recovery in colonies east of the North Cape, there are fears that what were once among the largest colonies in Europe are now on the brink of extinction (Røst 16,000 pairs in 1960-63, Sør-Fugløy 10,000 pairs in 1940, Nord-Fugløy 15,000 pairs in 1963, and Hjelmsøya ca. 100,000 pairs in the mid-1960s) (Soot-Ryen 1941, Lütken 1965, Brun 1969, Tschanz and Barth 1978). This may be through a breakdown of the social structure on the breeding shelves and/or increasing disturbance pressure from Whitetailed Eagles Haliaeetus albicilla (Barrett et al. 2006). As a result, the Common Guillemot population is now classified as 'Critically Endangered' (CR) on the Norwegian Red List (Kålås et al. 2006).

Most of the Norwegian and Russian Brünnich's Guillemots breed much further north in the Barents Sea, mainly in Svalbard, Franz Josef Land and on Novaya Zemlya where populations have recently been estimated to be $c a$. 850,000, 25,000 and 850,000 pairs respectively (Bakken and Pokrovskaya 2000). There have also been large declines in this population. For example, in the largest colony on Novaya Zemlya numbers have dropped from $>_{1.5}$ million individuals in the 1930s to 100,000-150,000 individuals in the early 1990s. A second colony of 200,000 individuals in 1920 is now abandoned (Krasnov and Barrett 1995, Bakken and Pokrovskaya 2000). Long-term monitoring in Svalbard since 1986 has so far indicated a stable population (Strøm 2006). At the southern edge of their distribution, on the mainland coast of North Norway and the Kola Peninsula, the population has recently been estimated at 3,000-5,000 individuals although little is known about recent developments (Krasnov et al. 2007).

Both species also breed along the coasts of many North Atlantic seaboard countries and are very faithful to their breeding site, but outside the breeding season, birds from many regions may gather at sea in large flocks such that any 'incident' may involve birds from several breeding populations simultaneously (Strann et al. 1991, Bakken et al. 2003, Cadiou et al. 2004). In these cases, to be able to assess the scale of the impact through the identification of the source populations is of utmost importance for the management of those populations.

With the present focus on oil and gas exploration, production and transport from the Barents Sea, the possibility of the northern populations of guillemots being directly affected by a spill is increasing. Furthermore the direct and indirect pressures on individuals by fishing activity in the region are ever-present such that the possibility of a mass mortality incident is always present. Because at least the Common Guillemot population in the Barents Sea is already seriously threatened, there is a need to be able to identify the origin of birds killed in oil incidents in order to document effects at the population level and identify any mitigating post-event management actions.

Traditionally, the recovery of ringed birds and the examination of structural size has been used to identify the origins of the victims of wrecks or oil spills (Anker-Nilssen et al. 1988, Camphuysen and Leopold 2004, Cadiou et al. 2004, Grantham 2004) through the fact that body size often increases with latitude (e.g. Anker-Nilssen et al. 1988, Jones 1988a, Barrett et al. 1997). Other characteristics such as slight changes in plumage colour and, among Common Guillemots, a north-south cline in the proportion of bridled birds (Birkhead 1984) have proved to be of limited value in such studies. Recently much effort has been put into population genetic studies, partly in the hope that there is enough genetic differentiation among colonies to be able to identify the geographical origins of birds found outside the breeding season. For both guillemot species, however, the populations were found to be so weakly structured that any clear assignment of birds to their origin is impossible using this method alone (Moum et al. 1991, 
Birt-Friesen et al. 1992, Moum and Arnason 2001, Riffault et al. 2005). Another approach has been through the use of stable-isotope analyses of feathers but this method is also limited in its precision (Cherel et al. 2000). Thus, as yet, the use of biometrics still produces the best management advice.

Jones (1988a) documented a clear latitudinal cline in Common Guillemot wing length based on measurements made in 13 colonies from Skomer in West Wales in the south to Vardø in Northeast Norway in the north, while Gaston et al. (1984) found a small but significant intercolony phenotypic variation among Brünnich's Guillemot colonies in the Hudson Strait, Canada. Until now, the only systematic data published from Norway were based on museum skins (Pethon 1967), but these are of limited value in this context due to e.g. shrinkage (Harris 1980, Jones $1988 \mathrm{~b}$ ) and often unknown measuring techniques.

To facilitate the identification of the origins of birds killed by oil spills, fishing gear or starvation outside their breeding areas, we here present recent measurements of live Common Guillemot from eight Norwegian colonies, one from Iceland and one from Northwest Russia (Figure I) and compare them to published measurements from other colonies in the Northeast Atlantic. We also present for the first time biometrical data of Brünnich's Guillemots from eight breeding colonies in the Barents Sea.

\section{Material and methods}

One Russian and seven Norwegian Common Guillemot colonies (Figure 1) were visited either once (Runde), twice (Bleiksøya, Hjelmsøya, Syltefjord) or over several years (Røst, Hornøya, Bjørnøya, Kharlov) and measurements were made of birds caught on the breeding sites (open ledges or natural cavities inside boulder screes). At a ninth colony, Loppa, measurements were taken of birds drowned in fishing nets under the cliff. Measurements of Brünnich's Guillemots were also made of birds caught in the breeding colonies during single or repeated visits to eight

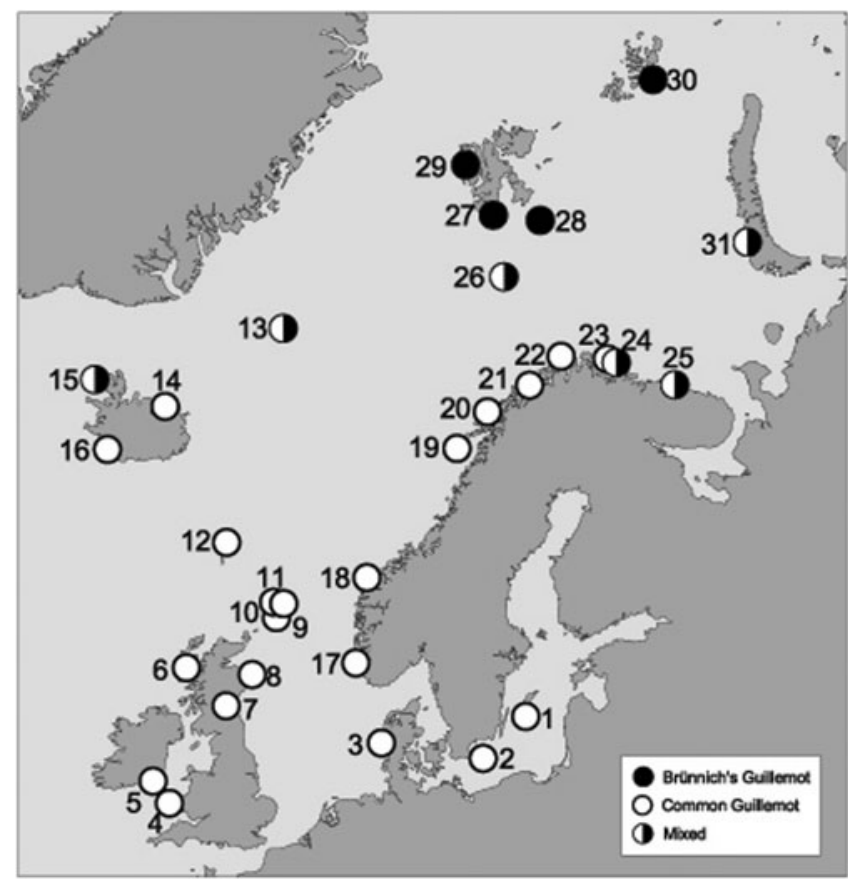

Figure 1. Approximate positions of the colonies mentioned in the text. Numbers by each symbol are colony numbers in Tables 3 and 4 . 
colonies in the Barents Sea. Samples of both species were measured during a visit to Latrabjarg, Northwest Iceland.

The following measurements were taken: body mass $( \pm 2.5 \mathrm{~g})$, wing length (maximum flattened chord $\pm 0.5 \mathrm{~mm}$ ), culmen length (from tip of bill to proximal edge of horny sheath of the upper bill, $\pm 0.05 \mathrm{~mm}$ ), gonys depth (vertical depth of bill at gonys perpendicular to cutting edge of bill $\pm 0.05 \mathrm{~mm}$ ) and head + bill length $( \pm 0.05 \mathrm{~mm}) .95 \%$ confidence limits $(\mathrm{cl})$ of the means were calculated taking inter-observer variability of measurements into account using the equation $\mathrm{cl}= \pm t \sqrt{ }\left[(S D)^{2} / 2+\left(S_{R}\right)^{2}\right]$ where $t=$ student's $t$ when probability $P=0.05, \mathrm{SD}=$ standard deviation of mean and $S_{R}=$ inter-observer variability of wing measurements of large auks (Barrett et al. 1989).

In an attempt to assign individuals to population, we used not only colony-based measurements but also grouped the Norwegian and Russian Common Guillemots by region Svalbard ( 1 colony), North Norway and Russia (7 colonies), and South Norway (I colony) (Table 3 ) - and by sea area: Barents Sea (6 colonies - nos. 21-26 in Table 3) and Norwegian Sea (3 colonies - nos. 18-20 in Table 3). To test the accuracy of the method, we used the discriminant function of SPSS (ver. 15.0, SPSS Inc.) to predict the group membership of each bird according to colony, region and sea area.

Mean sea surface temperatures in May-July were taken from Levitus (1982) and Steffánsson (1969).

\section{Results}

\section{Common Guillemot}

The biometric characteristics of Common Guillemots examined were significantly different across the eight Norwegian and one Russian colony (ANOVA tests, $P<0.001$ in all cases) and indicates a clear increase in size from southwest to northeast (Table 1 ). This is reflected in positive correlations between body mass (mass) and latitude (lat) (mass $=-48.4+15.112 \mathrm{x}$ lat, $\left.r^{2}=0.78, P=0.004\right)$ and wing length (wing) and latitude (wing $=160.9+0.737 \times$ lat, $r^{2}=0.71$, $P=0.003$ ). Correlations of gonys depth, culmen or head + bill lengths with latitude were, however, insignificant.

When all published wing length data from other NE Atlantic colonies are included (Fig. I), there is a clear correlation between mean wing length and latitude throughout the range of the

Table 1. Body mass (g) and morphometric measurements ( $\mathrm{mm}$ ) of adult Common Guillemots in Norwegian, Northwest Russian and Icelandic breeding colonies. The geographic coordinates of each colony are given in Table 3 .

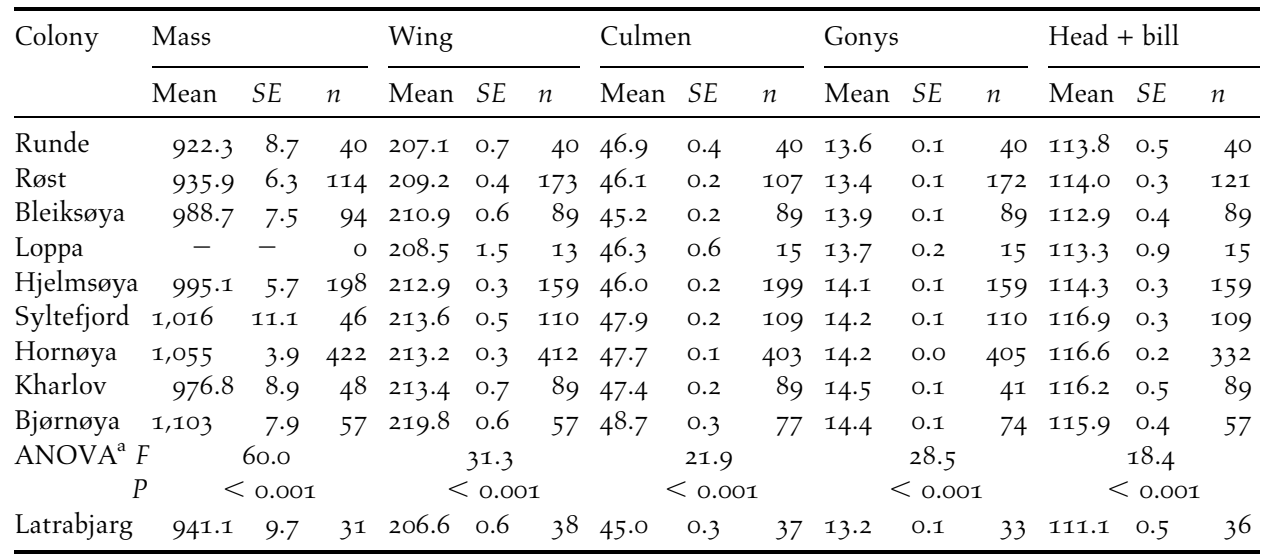

${ }^{\mathrm{a}}$ Among Norwegian and Russian colonies. 
Common Guillemot (wing $=158.8+0.763 \mathrm{x}$ lat, $r^{2}=0.78, P<0.001$, Figure 2 ). Excluding the Icelandic birds, which are outside the main SW-NE axis, increases the correlation to $88 \%$. There is also a slightly weaker correlation with the mean summer sea surface temperature (sst) around the colonies (wing $=220.2-1.530 \mathrm{x}$ sst, $r^{2}=0.71, P<0.001$, Figure 2). Again excluding the Icelandic birds increases the correlation to $81 \%$. There is, however, considerable overlap of the $95 \%$ confidence intervals of the means along the SW-NE cline when inter-observer variability is taken into account (Figure 2).

Based on wing length alone, the discriminant function only classified $15 \%$ of the birds to the correct colony, whereas $51 \%$ were classified to the correct region and $64 \%$ to the correct sea
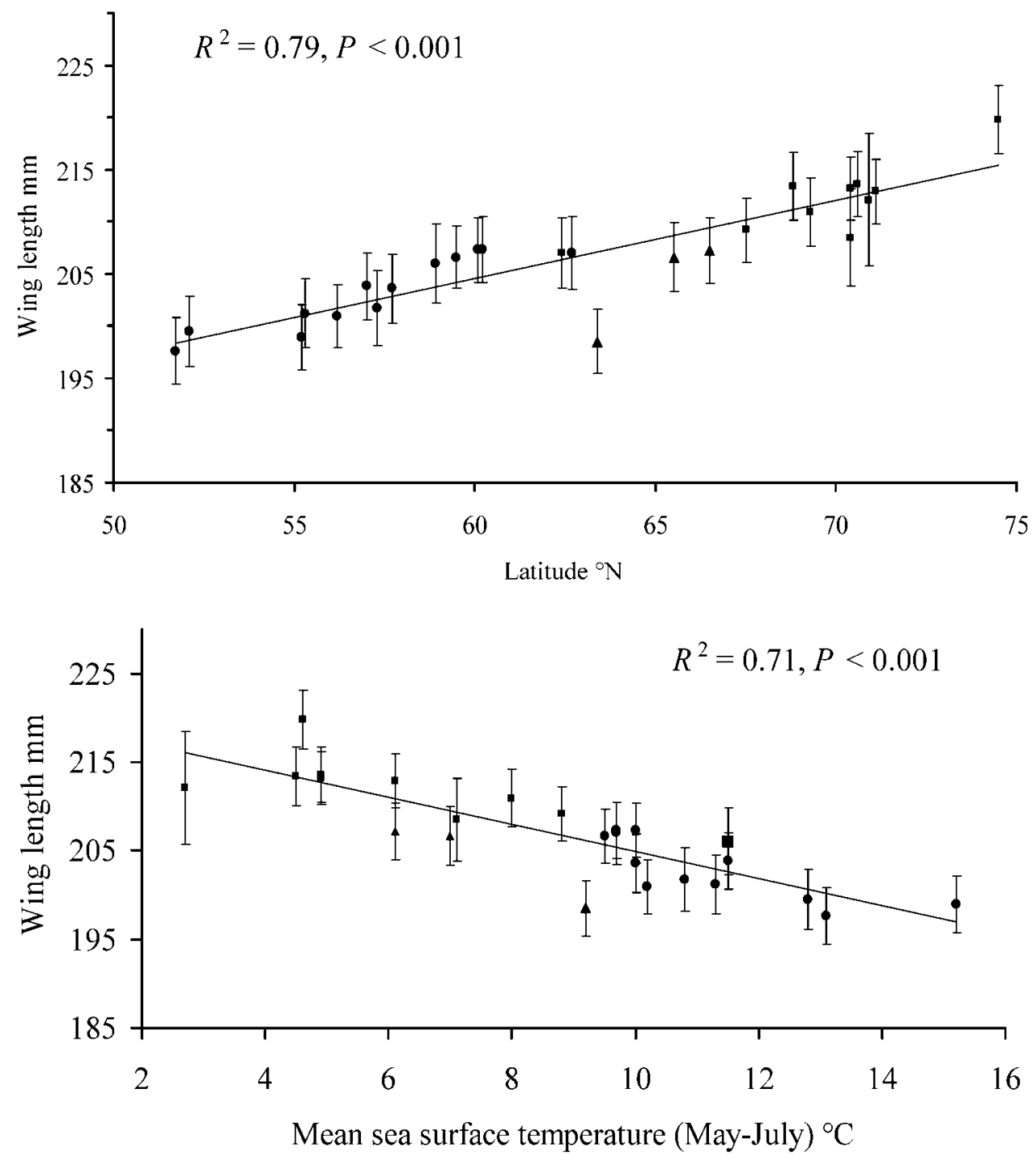

Figure 2. Plots of mean wing lengths of East Atlantic Common Guillemots in relation to latitude of colony and mean sea surface temperature. $95 \%$ confidence limits of means taking into account inter-observer variability of measurements (see methods) are shown. Data from Table 3. Square symbols $=$ Norway and Russia, triangles = Iceland, dots = UK; from Jones (1988). 
area. When including head + bill length the corresponding accuracy estimates for colony and sea area increased to $20 \%$ and $69 \%$, respectively, whereas that for region dropped only slightly to $48 \%$. It should be noted that the Box's $M$ test for homogeneity of population covariances tested unequal in most cases. However, this test is particularly sensitive to deviations from multivariate normality, which we could expect from differences in sample sizes and measuring techniques among the observers (Barrett et al. 1989), as well as from probable natal dispersal of birds between the colonies (Nikolaeva et al. 1996).

\section{Brünnich's Guillemot}

There were again clear and significant $(P<0.001$ in all cases $)$ differences in mean measurements among the Barents Sea colonies (Table 2), but no obvious pattern with regards to geographical location within the Barents Sea. Furthermore, there were no significant correlations between any of the measurements and latitude or mean summer sea surface temperature with or without the inclusion of the Iceland and Jan Mayen colonies (Table 4, Figure 3). There was again considerable overlap of the $95 \%$ confidence intervals of the means.

\section{Discussion}

One major problem faced when comparing body measurements of birds is the inconsistency of repeat measurements among and between observers (Gaston et al. 1984, Ewins 1985, Barrett et al. 1989). Mass is probably the easiest and thus the most consistent to determine, but because body mass varies considerably throughout the year, it is useless as a parameter by which to determine a bird's origin. Of the others measured in this study, wing and head + bill have previously been shown to be most consistently measured (Barrett et al. 1989).

Furthermore, only slight variations in parameter definitions can preclude direct comparisons of measurements. For example, while culmen length is now generally measured from the bill tip to the proximal edge of the sheath, Storer (1952) measured from the bill tip to the "base of the anteriormost feathers", thereby presumably including the small patch of bare skin just behind the sheath. Likewise, gonys depth, as measured here, is not the same as Storer's measurement of bill depth (he measured vertically at the level of the anteriormost feathers), again precluding direct comparisons.

Table 2. Body mass (g) and morphometric measurements (mm) of adult Brünnich's Guillemots in Norwegian, Northwest Russian and Icelandic breeding colonies. The geographic coordinates of each colony are given in Table 4 .

\begin{tabular}{|c|c|c|c|c|c|c|c|c|c|c|c|c|c|c|}
\hline \multirow[t]{2}{*}{ Colony } & \multicolumn{3}{|l|}{ Mass } & \multicolumn{3}{|l|}{ Wing } & \multicolumn{3}{|c|}{ Culmen } & \multicolumn{3}{|l|}{ Gonys } & \multicolumn{2}{|c|}{ Head + bill } \\
\hline & Mean & $S E$ & $n$ & Mean & $S E$ & $n$ & Mean & $S E$ & $N$ & Mean & $S E$ & $n$ & Mean $S E$ & $n$ \\
\hline Hornøya & 999.6 & 3.7 & 323 & 222.2 & 0.3 & 322 & 37.5 & 0.2 & 312 & 14.6 & 0.1 & 312 & $105.5 \quad 0.2$ & 298 \\
\hline Kharlov & 936.9 & 27.1 & 8 & 219.0 & 0.7 & 43 & 37.8 & 0.3 & 43 & 14.5 & 0.1 & 35 & 105.80 .5 & 43 \\
\hline Bjørnøya & 1,068 & $9 \cdot 5$ & 51 & 224.4 & 0.6 & 51 & $37 \cdot 3$ & 0.3 & 82 & $14 \cdot 3$ & 0.1 & 82 & $103.5 \quad 0.4$ & 51 \\
\hline Hopen & 987.1 & 9.2 & 68 & 222.2 & 0.5 & 77 & 36.3 & 0.2 & 74 & 14.2 & 0.1 & 76 & $\begin{array}{lll}104.1 & 0.4\end{array}$ & 75 \\
\hline Kovalskifjellet & 929.6 & 12.6 & 25 & 220.7 & 0.9 & 35 & 33.8 & 0.5 & 33 & 15.0 & 0.3 & 35 & $99.4 \quad 0.5$ & 35 \\
\hline Ny-Ålesund & 891.1 & 31.4 & 14 & 219.3 & 1.1 & 32 & 38.0 & 0.1 & 32 & 14.0 & 0.1 & 31 & $104.5 \quad 0.4$ & 31 \\
\hline Rubini Rock & 923.0 & 12.2 & 30 & 220.5 & 0.9 & 30 & $37 \cdot 7$ & 0.4 & 30 & - & - & o & 107.10 .6 & 30 \\
\hline $\begin{array}{l}\text { Bezymyannaya } \\
\text { Bay }\end{array}$ & 969.4 & 6.8 & 81 & 217.0 & 0.6 & 81 & $37 \cdot 7$ & 0.2 & 81 & $14 \cdot 3$ & 0.1 & 50 & 107.60 .4 & 81 \\
\hline ANOVA $^{\mathrm{a}} F$ & & $23 \cdot 3$ & & & 14.1 & & & 11.4 & & & 8.0 & & 28.4 & \\
\hline$P$ & & 0.00 & & & 0.0 & & & 0.00 & & & 0.0 & & $<$ o.o & \\
\hline Latrabjarg & $897 \cdot 4$ & 14.1 & 35 & $217 \cdot 7$ & 0.6 & 42 & $35 \cdot 5$ & 0.3 & 42 & 13.8 & 0.1 & 42 & 102.50 .5 & $4^{2}$ \\
\hline
\end{tabular}

${ }^{a}$ Among Barents Sea colonies. 
Table 3. Wing lengths ( $\mathrm{mm})$ of Common Guillemots breeding in the Northeast Atlantic. The positions of each colony are shown by number in Fig. 1 . ucl, lcl = upper and lower $95 \%$ confidence limits (see methods), $n=$ sample size.

\begin{tabular}{|c|c|c|c|c|c|c|c|c|c|}
\hline No. & Colony & Country/Area & ${ }^{\circ} \mathrm{N}$ & ${ }^{\circ} \mathrm{E}$ & Mean & ucl & lcl & $n$ & Source \\
\hline 1 & Stora Karlsö & Baltic Sea & $57 \cdot 3$ & 18.0 & 201.7 & 191.8 & 211.6 & 28 & Salomonsen 1944 \\
\hline 2 & Graesholm & Baltic Sea & $55 \cdot 3$ & $15 \cdot 7$ & 201.2 & 191.8 & 210.6 & 46 & Jones 1988a \\
\hline 3 & Helgoland & North Sea & 55.2 & $7 \cdot 9$ & 198.9 & 195.0 & 202.8 & 25 & $\begin{array}{l}\text { O Hüppop pers. } \\
\text { comm. }\end{array}$ \\
\hline 4 & Skomer & SW Wales & 51.7 & -5.2 & 197.6 & 187.8 & $207 \cdot 4$ & 84 & Jones 1988a \\
\hline 5 & Great Saltee & SE Ireland & 52.1 & -6.7 & 199.5 & 191.3 & $207 \cdot 7$ & 35 & Jones 1988a \\
\hline 6 & Canna & NW Scotland & 57.0 & -6.5 & 203.8 & 193.8 & 213.8 & 91 & Jones 1988a \\
\hline 7 & Isle of May & SE Scotland & 56.2 & -2.6 & 200.9 & 190.9 & 210.9 & 351 & Jones 1988a \\
\hline 8 & Troop Head & NE Scotland & $57 \cdot 7$ & -2.3 & 203.6 & 195.7 & 211.5 & 39 & Jones 1988a \\
\hline 9 & Fair Isle & Shetland & $59 \cdot 5$ & -1.5 & 206.6 & 197.7 & $215 \cdot 5$ & 252 & Jones 1988a \\
\hline 10 & Foula & Shetland & 60.1 & -2.1 & $207 \cdot 3$ & 204.1 & 210.5 & 38 & Jones 1988a \\
\hline 11 & Noss & Shetland & 60.2 & -1.0 & $207 \cdot 3$ & $199 \cdot 3$ & $215 \cdot 3$ & 65 & Jones 1988a \\
\hline 12 & Eysturoy & Faeroes & 62.7 & -6.9 & 207.0 & 199.8 & 214.2 & 19 & Jones 1988a \\
\hline 13 & Jan Mayen & Norwegian Sea & 70.9 & -8.7 & 212.1 & 197.9 & 226.3 & 7 & Camphuysen 1989 \\
\hline 14 & Grimsey & NE Iceland & 66.5 & -18.0 & 207.2 & 199.6 & 214.8 & 60 & Jones 1988a \\
\hline 15 & Latraberg & NW Iceland & 65.5 & $-24 \cdot 4$ & 206.6 & 198.5 & $214 \cdot 7$ & 38 & This study \\
\hline 16 & Ellidaey & SW Iceland & 63.4 & -20.2 & 198.5 & 188.4 & 208.6 & 150 & Grandjean 1972 \\
\hline 17 & Rott & S Norway & 58.9 & $5 \cdot 5$ & 206.0 & 198.5 & 213.5 & 13 & Pethon 1967 \\
\hline 18 & Runde & S Norway & 62.4 & 5.6 & 207.1 & 197.5 & 216.7 & 40 & This study \\
\hline 19 & Røst & N Norway & $67 \cdot 5$ & 12.1 & 209.2 & 198.7 & 219.7 & 173 & This study \\
\hline 20 & Bleiksøya & N Norway & $69 \cdot 3$ & 15.9 & 210.9 & 199.4 & 222.4 & 89 & This study \\
\hline 21 & Loppa & N Norway & 70.4 & 21.4 & 208.5 & 196.3 & 220.7 & 13 & This study \\
\hline 22 & Hjelmsøya & N Norway & 71.1 & $24 \cdot 7$ & 212.9 & 204.2 & 221.6 & 159 & This study \\
\hline 23 & Syltefjord & N Norway & 70.6 & 30.3 & 213.6 & 202.6 & 224.6 & 110 & This study \\
\hline 24 & Hornøya & N Norway & 70.2 & 31.1 & 213.2 & 202.1 & $224 \cdot 3$ & 412 & This study \\
\hline 25 & Kharlov & NW Russia & 68.8 & $37 \cdot 3$ & 213.4 & 200.5 & 226.3 & 89 & This study \\
\hline 26 & Bjørnøya & Svalbard & $74 \cdot 5$ & 19.0 & 219.8 & 216.7 & 222.9 & 57 & This study \\
\hline
\end{tabular}

Among Common Guillemots, only wing length, with two exceptions, showed a clear geographic pattern in this study. Within the Norwegian samples, birds from Loppa had somewhat shorter wings than expected at the given latitude (Figure 2). Whereas the birds caught in all the other colonies were breeding adults, the Loppa birds were caught in nets below the cliffs. Eight of the 13 birds whose wings were measured had cloacal bursae of Fabricius and were thus immature and hence probably shorter winged than adults (Glick 1983). Similarly, the Icelandic outlier in Figure 2 (from Ellidaey) may also be due the inclusion of immature birds in the sample as Grandjean (1972) did not specify that the birds caught were only breeding adults and further suggests that the shorter wings may have been due to feather wear as the birds were caught late in the breeding season.

The increase in wing length with latitude in Common Guillemots in the East Atlantic is similar to that in the East Pacific where Californian birds have shorter wings than those in Alaska (Storer 1952). However, while the cline continues to the northeastern limit of distribution in the Atlantic (thus supporting de Wijs' (1978) suggestion to merge the race hyperborea with the nominate race), those from North Alaska and the Bering Sea are smaller in all measurements than those from southern Alaska (Storer 1952). Among Brünnich's Guillemots, this north-south cline seems to be reversed in eastern Canada with longer-winged birds breeding in the Gulf of St. Lawrence than in Arctic Canada (Storer 1952). There is, however, considerable variation in body size among colonies e.g. within the Hudson Strait (Gaston et al. 1984, Gaston and Jones 1998), suggesting factors other than the physical environment (SST, latitude) are operating. 
Table 4. Wing lengths (mm) of Brünnich's Guillemots breeding in the Northeast Atlantic. The positions of each colony are shown by number in Fig. 1 . ucl, $\mathrm{lcl}=$ upper and lower $95 \%$ confidence limits (see methods), $n=$ sample size.

\begin{tabular}{llllllllll}
\hline No. & Colony & Country/Area & ${ }^{\circ} \mathrm{N}$ & ${ }^{\circ} \mathrm{E}$ & Mean & $\mathrm{lcl}$ & $\mathrm{ucl}$ & $n$ & Source \\
\hline 13 & Jan Mayen & Norwegian Sea & 70.9 & -8.7 & 224.5 & 214.5 & 234.5 & 7 & Camphuysen \\
& & & & & & & & & 1989 \\
15 & Latraberg & NW Iceland & 65.5 & -24.4 & 217.7 & 209.3 & 226.1 & 38 & This study \\
24 & Hornøya & N Norway & 70.2 & 31.1 & 222.2 & 211.2 & 233.2 & 322 & This study \\
25 & Kharlov & NW Russia & 68.8 & 37.3 & 219.0 & 209.2 & 228.8 & 43 & This study \\
26 & Bjørnøya & Barents Sea & 74.5 & 19.0 & 224.4 & 215.3 & 233.5 & 51 & This study \\
28 & Hopen & SE Svalbard & 76.6 & 25.3 & 222.2 & 213.0 & 231.4 & 77 & This study \\
27 & Kovalskifjellet & S Svalbard & 77.1 & 17.1 & 220.7 & 209.5 & 231.9 & 35 & This study \\
29 & Ny-Ålesund & NW Svalbard & 78.9 & 11.9 & 219.3 & 206.2 & 232.4 & 32 & This study \\
30 & Rubini Rock & Frans Josef Land & 80.3 & 52.8 & 220.5 & 210.0 & 231.0 & 30 & This study \\
31 & Bezymyannaya Bay & Novaya Zemlya & 72.9 & 53.1 & 217.0 & 205.4 & 228.8 & 81 & This study \\
\hline
\end{tabular}
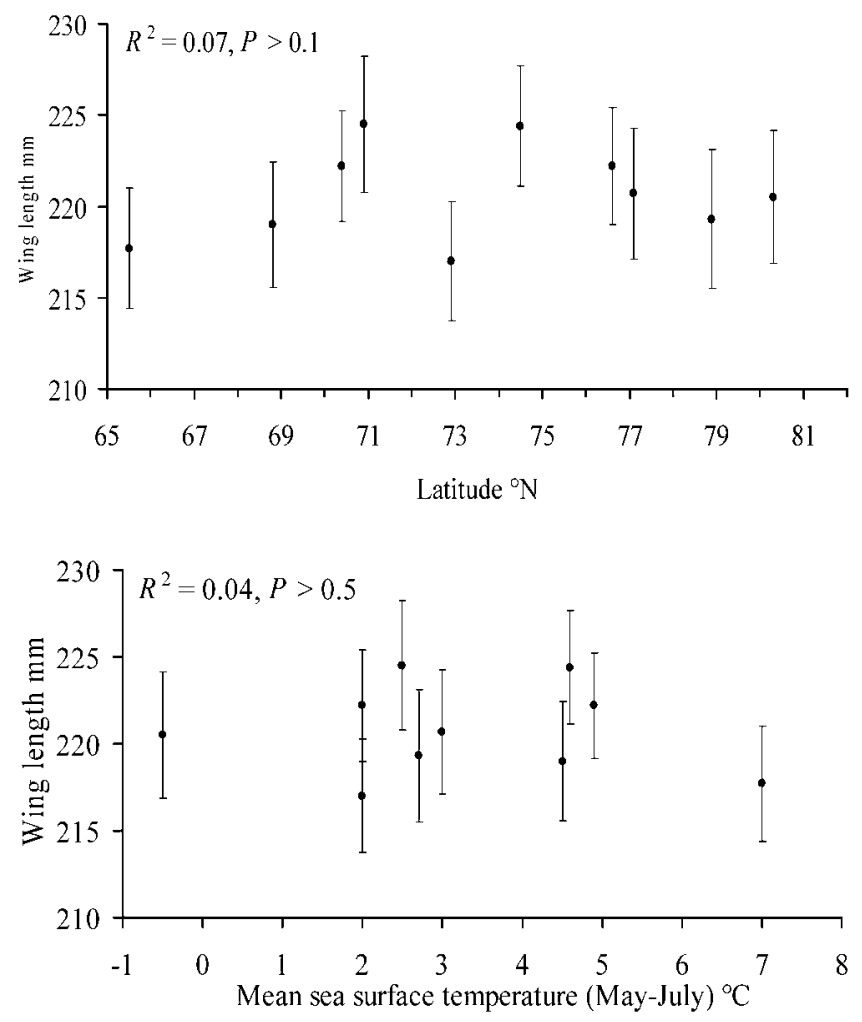

Figure 3. Plots of mean lengths of East Atlantic Brünnich's Guillemots in relation to latitude of colony and mean sea surface temperature. $95 \%$ confidence limits of the means taking into account inter-observer variability of measurements (see methods) are shown. Data from Table 4.

Whereas there was no consistent pattern of geographical variation among Brünnich's Guillemots in the NE Atlantic (this study), a comparison with data from the NW Atlantic substantiates Gaston and Jones' (1988) suggestion that North American birds are smaller than European birds (Fig. 4). Our data also place the Icelandic birds in the North American group, 
whereas those from Jan Mayen are similar in size to those from Europe (Fig. 4). The only exception in this pattern were birds from Kovalskifjellet, Spitsbergen whose wings were long but whose culmens (and head + bill) were much shorter than their European counterparts (Table 2, Fig. 4). With the winter movements of Spitsbergen and probably also other Barents Sea Brünnich's Guillemots across to Greenland and Newfoundland (Nikolaeva et al. 1996, Bakken and Mehlum 2005), this size differentiation provides a means of detecting any European birds among those shot during the annual turr hunt in the Northwest Atlantic and hence evaluating the effect of the hunt on the mortality of adult European birds.

The absence of any phenotypic pattern among the Barents Sea Brünnich's Guillemots may be due to the northerly restriction of their breeding distribution. Furthermore, Friesen et al. (1996) found no genetic variation among North Atlantic Brünnich's Guillemots and suggested that this may be due to the establishment of all colonies from a single refugial population that survived the Pleistocene glaciation and that was so recent that there has been insufficient time for the evolution of colony-specific markers. This is further enhanced by the mixing of the whole Barents Sea population outside the breeding season, with large numbers of birds remaining in the area both at sea, near the coast and in ice-covered waters after the breeding season and over winter (Fauchald et al. 2004, Bakken and Mehlum 2005 and references therein). This probably also applies to an unknown proportion of the population that moves out of the region and winters off Iceland, Greenland and Northeast Canada (Nikolaeva et al. 1996, Bakken and Mehlum 2005). As a result, the chances of birds from different colonies joining recruits to other colonies and thus returning to non-natal colonies throughout the region are high. Such lack of philopatry has been documented through observations of ringed adult and immature birds (Nikolaeva et al. 1996) and would contribute to the low genetic and phenotypic variation demonstrated for this species (Birt-Friesen et al.1992, this study)

That the North Atlantic Common Guillemot colonies constitute a largely panmictic population with a low level of genetic differentiation (Moum and Arnason 2001, Cadou et al. 2004, Riffault et al. 2005) is corroborated by the lack of consistent variation in most of the body measurements presented here. There is, however, evidence that it is derived from two or more Pleistocene refugia, one in the far Northeast Atlantic (possibly Barents Sea) and one further south. Secondary contact between these genetically differentiated populations could result in a

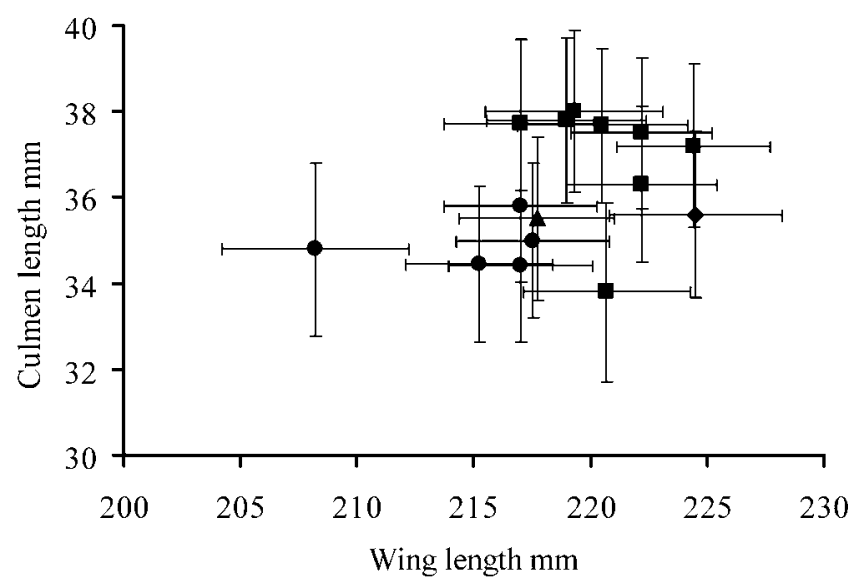

Figure 4. Plot of culmen length versus wing length for Brünnich's Guillemot populations. 95\% confidence limits of means taking into account inter-observer variability of measurements (see methods) are shown. Squares $=$ Norway and Russia, triangle $=$ Iceland, diamond $=$ Jan Mayen (all from Table 4); dots = East Canada (from Gaston and Nettleship (1981), Gaston et al. (1984) and Birkhead and Nettleship (1987)). 
cline between the two (Friesen et al. 1996). Such secondary contact is common among European Common Guillemots whose post-breeding migratory/dispersal patterns, although somewhat differentiated (Harris and Swan 2002), does result in some mixing of populations along the coast of the North Sea and Norway (Strann et al. 1991, Bakken et al. 2003). Many young birds also recruit into non-natal colonies (Harris et al. 1996) and there is repeated documentation of longdistance dispersal of Common Guillemots from one colony to another (Halley and Harris 1993, Lyngs 1993, Nikolaeva et al. 1996, Harris and Swann 2002). Such contact between the two populations may, in time, have led to the clinal variations in wing length (this study) and the frequency of bridling (Birkhead 1984).

There is a clear south-north phenotypic cline in wing length among Common Guillemots, but the large confidence intervals that result from data being collected by different observers precludes more than a rough identification of the origins of birds found away from their colonies (Fig. 2). This is corroborated by our discriminant analyses, which indicated that although our method of identifying the origin of Common Guillemots based on their biometrics is not very accurate at the colony level, it performs relatively well at the region and sea area level, provided one has a reasonably large sample of adult birds. This assumes that the variance among those taking part in Barrett et al's (1989) study was similar to that among those who measured birds in the present study. This is a reasonable assumption as most of the measurements were made by experienced researchers. A reduction in the confidence intervals is possible only by a large increase in the sample sizes for each colony when several measurers are involved. An alternative is that all measurements are made by one observer in all colonies (Barrett et al. 1989) although this is obviously very impractical as it would also entail that same observer would need to measure all the birds examined in an 'incident'.

Despite this limitation, however, and until other genetic markers are found (Riffault et al. 2005), careful measurements of wing and head + bill lengths are still the only simple direct determinant of the origin of unringed adult Northeast Atlantic Common Guillemots, as is also the case for Atlantic Puffins Fratercula arctica and Razorbills Alca torda (Barrett et al. 1985, 1997, Anker-Nilssen et al. 2003). It is thus likely that if, for instance, such a series of measurements had existed for Common Guillemots or Rhinoceros Auklets Cerorhinca monocerata breeding in the North Pacific, the origins of the birds caught in gill nets in Washington in the early 1990s might have been easier to determine than through observations of incubation patch refeathering (Thompson et al. 1998). Although we succeeded only in differentiating the origins of one of the two Uria guillemot species in the Northeast Atlantic, we recommend exploring further the use of biometrics as determinants of the breeding areas of seabirds or any other bird species with a wide latitudinal distribution range.

\section{Acknowledgements}

We thank our host institutions for partly financing the field work, numerous field assistants and colleagues who helped us catch and measure the birds and Karen McCoy and two referees for their comments on the manuscript. The final stages of this study were financed by SEAPOP, a newly-started Norwegian seabird programme for improved decision support in marine areas (http://www.seapop.no).

\section{References}

Anker-Nilssen, T. (1987) Metoder til konsekvensanalyser olje/sjøfugl. Viltrapport 44. Trondheim: Directorate for Nature Management.
Anker-Nilssen, T. and Røstad, O. W. (1982) Oljekatastrofen i Skagerrak ved årsskiftet 8o/81 - omfang og undersøkelser. Vår Fuglefauna 5: 82-90. 
Anker-Nilssen, T., Aarvak, T. and Bangjord, G. (2003) Mass mortality of Atlantic Puffins Fratercula arctica off Central Norway, spring 2002: causes and consequences. Atlantic Seabirds 5: 57-71.

Anker-Nilssen, T., Bakken, V., Strøm, H., Golovkin, A., Bianki, V. and Tatarinkova, I. P., eds. (2000) The status of marine birds breeding in the Barents Sea region. Norsk Polarinst. Rapportserie No. 113. Tromsø: Norwegian Polar Institute.

Anker-Nilssen, T., Jones, P. H. and Røstad, O. W. (1988) Age, sex and origins of auks (Alcidae) killed in the Skagerrak oiling incident of January 1981. Seabird 11: 28-46.

Bakken, V. and Mehlum, F. (2005) Wintering areas and recovery rates of Brünnich's guillemots Uria lomvia ringed in the Svalbard archipelago. Arctic 58: 268-275.

Bakken, V. and Pokrovskaya, I. V. (200o) Brünnich's Guillemot Uria lomvia. Pp. ${ }^{119-124}$ in T. Anker-Nilssen, V. Bakken, H. Strøm, A. Golovkin, V. Bianki and I. P. Tatarinkova, eds. The status of marine birds breeding in the Barents Sea region. Tromsø: Norsk Polarinst. Rapport Serie no. 113.

Bakken, V., Runde, O. and Tjørve, E. (2003) Norsk ringmerkingsatlas. Vol. 1. Stavanger: Stavanger Museum.

Bambulyak, A. and Frantzen, B. (2005) Oil transport from the Russian part of the Barents Region. Status per January 2005. Svanhovd: Svanhovd Environmental Centre.

Barrett, R. T. (1979) Small oil spill kills 1020000 seabirds in North Norway. Mar. Poll. Bull. 10: 253-255.

Barrett, R. T., Anker-Nilssen, T. and Krasnov, Y. V. (1997) Can Norwegian and Russian razorbills Alca torda be identified by their measurements? Mar. Ornithol. 25: 5-8.

Barrett, R. T., Fieler, R., Anker-Nilssen, T. and Rikardsen, F. (1985) Measurements and weight changes of Norwegian adult Puffins Fratercula arctica and Kittiwakes Rissa tridactyla during the breeding season. Ringing \& Migration 6: 102 112.

Barrett, R. T., Lorentsen, S.-H. and AnkerNilssen, T. (2006) The status of breeding seabirds in mainland Norway. Atlantic Seabirds 8: 97-126.

Barrett, R. T., Peterz, M., Furness, R. W. and Durink, J. (1989) The variability of biometric measurements. Ringing \& Migration 10: 13-16.

Birkhead, T. R. (1984) Distribution of the bridled form of the Common Guillemot Uria aalge in the North Atlantic. J. Zool. Lond. 202: 165-176.

Birkhead, T. R. and Nettleship, D. N. (1987) Ecological relationships between Common Murres, Uria aalge, and Thick-billed Murres, U. lomvia, at Gannet Islands, Labrador. I. Morphometrics and timing of breeding. Can. J. Zool. 65: 1621-1629.

Birt-Friesen, V., Montevecchi, W. A., Gaston, A. J. and Davidson, W. S. (1992) Genetic structure of Thick-billed Murre (Uria lomvia) populations examined using direct sequence analysis of amplified DNA. Evol. 46: $267-272$.

Brun, E. (1969) Utbredelsen og hekkebestand av lomvi (Uria aalge) i Norge. Sterna 8: 209-224.

Cadiou, B., Riffault, L., McCoy, K. D., Cabelguen, J., Fortin, M., Gélinaud, G., Le Roch, A., Tirard, C. and Boulinier, T. (2004) Ecological impact of the "Erika" oil spill: Determination of the geographic origin of the affected common guillemots. Aquat. Living Resour. 17: 369-377.

Camphuysen, C. J. (1989) Biometrics of auks at Jan Mayen. Seabird 12: 7-10.

Camphuysen, C. J. and Leopold, M. F. (2004) The Tricolor oil spill: Characteristics of seabirds found oiled in the Netherlands. Atlantic Seabirds 6: 109-128.

CamphuysenC. J., Wright, P. J., Leopold, M. F., Hüppop, O. and Reid, J. B. (1999) A review of the causes, and consequences at the population level, of mass mortalities of seabirds. Pp. 51-66 in R. W. Furness and M. L. Tasker, eds. Diets of seabirds and consequences of changes in food supply. ICES Coop. Res. Report No. 232. Copenhagen: International Council for the Exploration of the Sea.

Cherel, Y., Hobson, K. A. and Weimerskirch, H. (2000) Using stable-isotope analysis of feathers to distinguish moulting and breeding origins of seabirds. Oecologia 122: 155-162. 
de Wijs, W. J. R. (1978) De geographiese varietie van der zeekoet (Uria aalge, Pontoppidan) en de mogelijke relatie hiervan met de laat-Pleisticene geschiedenis van der Noor-delijke Atlantise Ocean. Ph.D. thesis. Univ. Amsterdam.

Ewins, P. (1985) Variation of Black Guillemot wing lengths post-mortem and between measurers. Ringing \& Migration 6: 115-117.

Fauchald, P., Langeland, K. and Erikstad, K. E. (2004) Utbredelse av sjøfugl $i$ Barentshavet. Grunnlagsrapport for inngangsdata til Miljorettet Risikoanalyse for område C, Barentshavet. Trondheim: NINA Oppdragsmelding 815.

Friesen, V. L., Montevecchi, W., Baker, A. J., Barrett, R. T. and Davidson, W. S. (1996) Population differentiation and evolution in the common guillemot Uria aalge. Mol. Ecol. 5: 793-805.

Furness, R. W., Thompson, D. R. and Harrison, N. (1994) Biometrics and seasonal changes in body composition of Common Guillemots Uria aalge from north-west Scotland. Seabird 16: 22-29.

Gaston, A. J., Chapdelaine, G. and Noble, D. G. (1984) Phenotypic variation among Thick-billed Murres from colonies in Hudson Strait. Arctic 37: 284-287.

Gaston, A. J. and Jones, I. L. (1998) Bird families of the world. The auks Alcidae. Oxford: Oxford University Press.

Gaston, A. J. and Nettleship, D. N. (1987) The Thick-billed Murrs of Prince Leopold Island. C. W. S. Monogr. Ser. No. 6. Ottawa: Canadian Wildlife Service.

Glick, B. (1983) Bursa of Fabricius. Pp. $443-500$ in D. S. Farner, J. R. King and K. C. Parkes, eds. Avian biology. Vol. 7. New York: Academic Press.

Grandjean, P. (1972) Some morphological observations on the guillemot (Uria aalge aalge Pont.) on Ellidaey, Westmann Islands. Dansk. Orn. Foren. Tidsskr. 66: 51-56.

Grantham, M. (2004) Age structure and origins of British and Irish guillemots Uria aalge recovered in recent European oil spills. Atlantic Seabirds 6(3/S.I.): 95-108.

Halley, D. J. and Harris, M. P. (1993) Intercolony movement and behaviour of immature guillemots Uria aalge. Ibis 135 : 264-270.

Harris, M. P. (1980) Post-mortem shrinkage of wing and bill of Puffins. Ringing $\mathcal{E}$ Migration 3: 60-61.

Harris, M. P., Halley, D. J. and Wanless, S. (1996) Philopatry in the Common Guillemot Uria aalge. Bird Study 43: 134-137.

Harris, M. P. and Swann, B. (2002) Common Guillemot (Guillemot) Uria aalge. Pp. 397-400 in C. V. Wernham, M. P. Toms, J. H. Marchant, J. A. Clark, G. M. Siriwardena and S. R. Baillie, eds. Migration Atlas: movements of the birds of Britain and Ireland. London: T. and A.D. Poyser.

Jones, P. J. (1988a) The European cline in wing-length of Guillemots Uria aalge. Seabird 11: 19-21.

Jones, P. J. (1988b) Post-fledging wing and bill development in the razorbill Alca torda islandica. Ringing \& Migration 9: 11-17.

Kålås, J. A., Viken, Å. and Bakken, T., eds. (2006) Norsk Rødliste 2006 - 2006 Norwegian Red List. Trondheim: Artsdatabanken.

King, J. G. and Sanger, G. A. (1979) Oil vulnerability index for marine oriented birds. Pp. 227-239 in J. C. Bartonek and D. N. Nettleship, eds. Conservation of marine birds of northern North America. Washington DC: Fish and Wildlife Service, Wildlife Research Report 11 .

Krasnov, J. V. and Barrett, R. T. (1995) Largescale interaction among seabirds, their prey and humans in the southern Barents Sea. Pp. $443-456$ in H. R. Skjoldal, C. C. E. Hopkins, K. E. Erikstad and H. P. Leinaas, eds. Ecology of fjords and coastal waters. Amsterdam: Elsevier Science.

Krasnov, Y. V., Barrett, R. T. and Nikolaeva, N. G. (2007) Status of Black-legged Kittiwakes Rissa tridactyla, Common Guillemots Uria aalge and Brünnich's Guillemots $U$. lomvia in Murman, NW Russia and in Varanger, NE Norway. Polar Res. 26: 113-117.

Levitus, S., ed. (1982) Climatological atlas of the world ocean. Rockville: NOAA Professional paper No. 13 . 
Lütken, E. (1965) Yngelfuglene på Nord-Fuglø, Nord-Norge, deres utbredelse og antal. Dansk. Orn. Foren. Tidsskr. 58: 166-193.

Lyngs, P. (1993) Colony interchange in Baltic guillemots Uria aalge. Dansk. Orn. Foren. Tidsskr. 87: 247-250.

Moum, T. and Arnason, E. (2001) Genetic diversity and population history of two related seabird species based on mitochondrial DNA control region sequences. Mol. Ecol. 10: 2463-2478.

Moum, T., Erikstad, K. E. and Bjørklid, E. (1991) Restriction fragment analysis of mitochondrial DNA in Common Murres, Uria aalge, from four Norwegian seabird colonies. Can. J. Zool. 69: 1577-1584.

Nikolaeva, N. G., Krasnov, Y. V. and Barrett, R. T. (1996) Movements of common Uria aalge and Brünnich's guillemots Uria lomvia breeding in the southern Barents Sea. Fauna Norv. Ser. C., Cinclus 19: 9-20.

Pethon, P. (1967) The systematic position of the Norwegian common murre (Uria aalge) and puffin (Fratercula arctica). Nytt Mag. Zool. 14: 84-95.

Riffault, L., McCoy, K. D., Tirard, C., Friesen, V. L. and Boulinier, T. (2005) Population genetics of the common guillemot Uria aalge in the North Atlantic: geographic impact of oilspills. Mar. Ecol. Prog. Ser. 291: $263-273$.
Salomonsen, F. (1944) The Atlantic Alcidae. Göteborgs Kung. Vetenskaps och Vitterhetssamhälles Handl, Följen 6, Ser. B 3: $1-138$.

Soot-Ryen, T. (1941) Egg- og dunvær i Troms Fylke. Tromsø Mus. Arshefter 62: 1-112.

Steffánsson, U. (1969) Sjávarhiti á siglingaleið umhverfis Island. Pp. 131-149 in M. A. Einarsson, ed. Hafísinn. Reykjavik: Almena Bókafélagid.

Storer, R. W. (1952) A comparison of variation, behaviour and evolution in the sea bird genera Uria and Cepphus. Univ. Calif. Publ. Zool. 52: 121-222.

Strann, K. -B., Vader, W. and Barrett, R. T. (1991) Auk mortality in fishing nets in North Norway. Seabird 13: 22-29.

Strøm, H. (2006) Brünnich's guillemot Uria lomvia. Pp. 163-166 in K. M. Kovacs and C. Lydersen, eds. Birds of Svalbard. Polarhåndbok No. 13. Tromsø: Norwegian Polar Institute.

Thompson, C. W., Wilson, M. L., Pierce, D. J. and DeGhetto, D. (1998) Population characteristics of common murres and rhinoceros auklets entangled in gillnets in Puget Sound, Washington, from 1993 to 1994. Northwestern Naturalist 79: 77-91.

Tschanz, B. and Barth, E. K. (1978) Svingninger i lomvibestanden på Vedøy på Røst. Fauna 31: 205-219.

\section{ROBERT T. BARRETT*}

Tromsø University Museum, Department of Natural Science, NO-9037 Tromsø, Norway.

\section{TYCHO ANKER-NILSSEN, TOMAS AARVAK}

Norwegian Institute for Nature Research, NO-7485 Trondheim, Norway.

\section{VIDAR BAKKEN, HALLVARD STRØM}

Norwegian Polar Institute, Polar Environmental Centre, NO-9296 Tromsø, Norway.

$V$. Bakken present address: Natural History Museum, University of Oslo, PO Box 1172, NO0318 Oslo, Norway.

\section{YURI KRASNOV}

Murmansk Marine Biological Institute, Vladimirskaya 17, Murmansk 183010, Russia.

*Author for correspondence; e-mail:rob.barrett@tmu.uit.no 